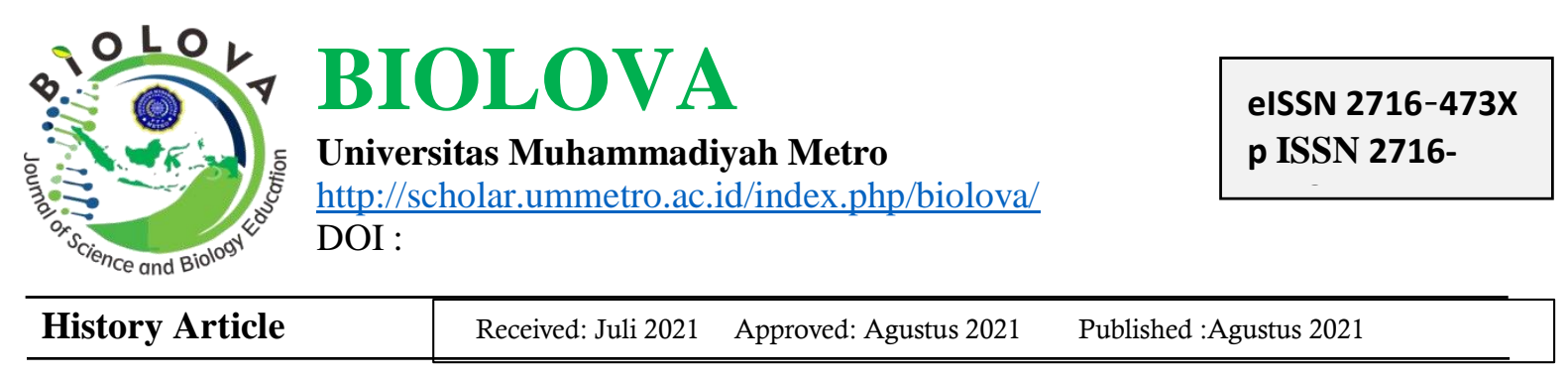

\title{
PENGEMBANGAN MODUL PEMBELAJARAN BIOLOGI (SISTEM ORGANISASI KEHIDUPAN ) BERBASIS E-LEARNING DENGAN EDMODO UNTUK MENINGKATKAN HASIL BELAJAR KOGNITIF SISWA
}

\author{
Candra Arityastuti Wijaya ${ }^{1}$, Muhfahroyin ${ }^{2}$ \\ ${ }^{1}$ SMPN 1 Purbolinggo Lampung Tengah, ${ }^{2}$ Program Pascasarjana/Magister Pendidikan Biologi/Universitas \\ Muhammadiyah Metro \\ ${ }^{1}$ E-mail: be5555nf@gmail.com, ${ }^{2}$ muhfahroyin@yahoo.com
}

\begin{abstract}
Abstrak: Pengembangan modul ini didasarkan pada proses pembelajaran yang sudah menggunakan media internet, namun pada kenyataannya pemanfaatannya selama proses pembelajaran belum maksimal dan media pembelajaran belum pernah dikembangkan berupa modul E-learning. tujuan dari penelitian ini adalah mengembangkan modul pembelajaran IPA (Biologi) pada materi sistem organisasi kehidupan untuk meningkatkan hasil belajar siswa dan mengetahui aktivitas virtual siswa dengan memanfaatkan aplikasi Edmodo. Model pengembangan yang dijadikan dasar penelitian ini dikemukakan oleh Trianto (2011:189) model pengembangan perangkat yang dikemukakan oleh Thiagarajan, Semmel dan Semmel pada tahun 1974 adalah model 4-D, model ini terdiri dari 4 tahap pengembangan yaitu define, merancang, mengembangkan, dan menyebarluaskan. Berdasarkan penjabaran yang telah dijelaskan di atas, dapat dikatakan bahwa modul pembelajaran biologi (IPA) berbasis E-learning dengan edmodo pada materi sistem organisasi kehidupan kelas VII SMP untuk meningkatkan hasil belajar kognitif siswa perlu diperhatikan sebagai penunjang dalam proses pembelajaran IPA.
\end{abstract}

Kata kunci:, e-learning, Edmodo, meningkatkan hasil belajar

Abstract: The development of this module is based on the learning process that already uses internet media, but in reality its use during the learning process has not been maximized and the learning media has never been developed in the form of E-learning modules. the purpose of this study was to develop a science learning module (Biology) in the material system of life organizations to improve student learning outcomes and find out virtual activities of students by utilizing Edmodo application. The development model used as the basis for this research is stated by Trianto (2011: 189) the device development model suggested by Thiagarajan, Semmel and Semmel in 1974 is a 4-D model, this model consists of 4 development stages, namely define, design , develop, and disseminate. Based on the elaboration that has been explained above, it can be said that the biology learning module (IPA) based on E-learning with edmodo on the material system of life organization class VII SMP to improve student cognitive learning outcomes need to be considered as a support in the learning process of Natural Sciences

Kata kunci: Modul, E-learning, Edmodo, meningkatkan hasil belajar.

\section{How to Cite}

Wijaya, Chandra Arityastuti, Muhfahroyin. 2021. Pengembangan Modul Pembelajaran Biologi (Sistem Organisasi Kehidupan) Berbasis E-Learning dengan Edmodo untuk Meningkatkan Hasil Belajar Kognitif Siswa. Biolova 2(2). 88-94. 
Saat ini Corona menjadi pembicaraan yang hangat. Di belahan bumi manapun, corona masih menjadi fokus penting setiap negara, karena dampak yang ditimbulkan sangat luas dari sektor ekonomi sampai sektor pendidikan. Dalam waktu singkat, Corona menjadi trending topik dan diberitakan secara masif di media cetak maupun elektronik. Severe Acute Respiratory Syndrome Coronavirus 2 (SARS-COV-2) atau yang lebih dikenal dengan nama virus corona adalah jenis baru dari coronavirus yang menyebabkan penyakit menular ke manusia.

Sektor pendidikan secara langsung terdampak dengan adanya virus Corona, pemerintah mengambil langkah kebijakan dengan melaksanakan pembelajaran secara daring (dalam jaringan), atau sistem pembelajaran yang dilakukan secara online, dengan melibatkan media informasi berupa aplikasi internet. Penting untuk menjadi perhatian oleh sekolah, guru dan orang tua untuk beradaptasi dengan sistem pembelajaran daring. Pembelajaran daring atau yang bisa juga dikatakan E-learning, memiliki tiga komponen pokok yaitu jaringan internet, plattform aplikasi yang digunakan, dan pendampingan oleh guru dan orangtua. Seperti yang dikemukakan oleh peneliti DeLone dan McLean (2003) menyatakan bahwa "model keberhasilan sistem informasi yaitu dengan enam variabel yaitu information quality, system quality, service quality, use, user satisfaction, and net benefit, karena proses pembelajaran idealnya adalah yang mampu mengantarkan peserta didik untuk berkembang dan dapat berpikir kritis yang kemudian menciptakan generasi penerus bangsa yang diharapkan".

Upaya mendukung pembelajaran yang baik, kondusif dan efektif ditengah pandemi adalah dengan meningkatkan kualitas pembelajaran daring dari aspekaspek teknis maupun kesiapan dari siswa dan orang tua. Kesiapan ini sangat menentukan keberhasilan proses pembelajaran karena setiap materi pembelajaran memiliki tingkat kesulitan yang berbeda-beda dalam hal penyampaian materi dan pemahamannya. Pembelajaran IPA (Ilmu Pengetahuan Alam) tentu memiliki karakteristik tersendiri dan perlu untuk menggunakan teknik tertentu dalam penyampaiannya, karena IPA merupakan ilmu yang menjadi dasar tolak ukur bagi perkembangan dan kemajuan teknologi. Prinsip dan teori-teori IPA dapat digunakan sebagai acuan untuk merancang dan menghasilkan peralatan dan teknologi baru yang berguna bagi kehidupan manusia.

Dengan adanya perkembangan tersebut, menjadikan profesionalisme seorang guru tidaklah hanya cukup jika sebatas memberikan materi pelajaran yang monoton (tidak menarik) terhadap siswa, tetapi guru juga diharapkan agar mampu mengelola lingkungan kelas menjadikan siswa merasa senang ketika menjalani proses belajar baik didalam kelas (secara langsung) mauapun secara daring.

Penggunaan Teknologi Informasi Komunikasi atau TIK dalam proses pembelajaran sangatlah membantu penyampaian pengetahuan/materi agar menjadi lebih mudah, mempercepat penyerapan bahan ajar, siswa dapat melakukan eksplorasi terhadap pengetahuannya secara lebih luas dan mandiri.

Mahnun (2012) menyebutkan bahwa "media berasal dari bahasa latin medium yang berarti perantara atau pengantar . Lebih lanjut, media merupakan sarana penyalur pesan atau informasi belajar yang hendak disampaikan oleh sumber pesan kepada sasaran atau penerima pesan tersebut".

Salah satu medianya adalah modul yang diciptakan oleh pengajar dalam bentuk satu paket lengkap yang tersusun secara sistematis, yang didalamnya terdapat bukan hanya teori-teori pembelajaran tetapi terdapat lembar kegiatan dan latihan-latihan soal.

Menurut Arsyad (2007) mengatakan bahwa "Proses pembelajaran terdapat beberapa aspek yaitu metode, pendekatan, model, dan media pembelajaran sebagai alat bantu mengajar. Kedudukan media 
pembelajaran ada dalam metode pembelajaran. Oleh karena itu fungsi utama dari media pembelajaran adalah sebagai alat bantu mengajar untuk menunjang penggunaan metode pembelajaran yang digunakan oleh guru".

Pada masa pandemi COVID-19 ini dimana siswa belajar dengan sistem daring (dalam jaringan) diperlukan suatu media Elearning untuk menunjang proses pembelajaran IPA. Edmodo merupakan salah satu media pembelajaran e-learning berbasis web. Pengoperasian edmodo sendiri hampir sama dengan Facebook, Twitter, dan media sosial lainnya tetapi Edmodo lebih menekankan pada aspek pembelajaran secara maya atau jarak jauh.

Dilihat dari segi tampilan aplikasi edmodo sangatlah user friendly atau mudah digunakan. Dimana tampilannya didesain sedemikian rupa sehingga mirip dengan facebook serta memiliki sistem kerja yang mirip dengan facebook sehingga memudahkan siswa untuk menggunakann edmodo. Dengan demikian akan sangat membantu guru dalam proses pembelajaran.

Berdasarkan hasil observasi di SMP Negeri 1 Purbolinggo diperoleh data sebagai berikut; 1) Proses pembelajaran IPA di SMP N 1 Purbolinggo sudah menggunakan media internet, tetapi pada kenyataannya penggunaannya selama proses pembelajaran belum dapat secara maksimal, 2) Pembelajaran Daring mengugunakan aplikasi WhatsApp (WA) dimana tugas siswa di foto kemudian dikirimkan ke group WA kelas yang ini sangat menyulitkan wali kelas umtuk mengkoreksi jawaban 3) proses pembelajaran di SMP N 1 Purbolingggo masih menggunakan buku paket dan LKS, 4) Belum pernah dikembangkan media pembelajaran berupa E- modul pembelajaran.

Berdasarkan permasalahan di atas, maka peneliti mengembangkan modul pembelajaran biologi (IPA) berbasis Elearning dengan edmodo pada materi sistem organisasi kehidupan kelas VII SMP untuk meningkatkan hasil belajar kognitif siswa, modul berbasis E-learning ini memiliki kelebihan sebagai sumber belajar mandiri bagi siswa, dan mewujudkan proses pembelajaran blended learning yang memadukan proses pembelajaran tatap muka dan pembelajaran secara daring, sehingga dapat meningkatkan hasil belajar kognitif siswa dan meningkatkan efektivitas pembelajaran.

Berdasarkan permasalahan tersebut maka didapatkan tujuan penelitian ini adalah untuk mengembangkan modul pembelajaran IPA (Biologi) pada materi sistem organisasi kehidupan untuk meningkatkan hasil belajar siswa dan mengetahui aktivitas virtual siswa dengan memanfaatkan aplikasi Edmodo.

\section{METODE}

Dasar pada penelitain ini adalah penelitian pengembangan, menurut Trianto (2011:189) "model pengembangan perangkat yang disarankan oleh Thiagarajan, Semmel dan Semmel pada tahun 1974 adalah model 4-D, model ini terdiri dari 4 tahap pengembangan, yaitu define, design, develop, dan disseminate atau didapatasikan menjadi model 4-P, yaitu pendefinisian, perancangan, pengembangan, dan penyebaran, untuk tahap penyebaran tidak akan diteliti dikarena terbatasnya waktu penelitian. Prosedur penelitian pengembangan tersebut diuraikan sebagai berikut:

\section{Tahap Pendefinisian (Define)}

Kegiatan pada tahap ini yaitu dilakukan untuk menetapkan permasalahan yang terdapat dalam suatu proses pembelajaran yang dilakukan dengan mendefinisikan syarat-syarat pengembangan. Tahapan ini dilakukan untuk menganalisis kebutuhan dalam proses pembelajaran. Tahap ini meliputi analisis ujung depan, analisis siswa, analisis konsep, analisis tugas, dan perumusan tujuan pembelajaran. 


\section{Tahap Perancangan (Design)}

Kegiatan pada tahap ini adalah pembuatan desain produk yang bertujuan untuk mengembangkan produk yang sistematis diantaranya meliputi penyusunan tes acuan patokan, pemilihan media, pemilihan format, dan rancangan awal.

\section{Tahap Pengembangan (Developing)}

Pada tahapan ini, pengembangan modul yang telah dibuat berdasarkan analisis-analisis kebutuhan peserta didik serta telah siap dicetak, langkah selanjutnya yaitu melakukan proses validasi. Validasi yang digunakan yaitu validasi isi dari modul. Validasi isi dalam penelitian ini, diperiksa oleh ahli yang berkompeten pada bidangnya, terkait masukan dan saran harus dicatat dan kemudian diperbaiki dan selanjutnya baru akan dilakukan uji coba pada sebuah kelas. Hasil dari validasi oleh ahli dan uji coba di kelas kemudian akan dianalisis untuk mendapatkan kesimpulan dari modul yang telah dikembangkan".

Subyek uji coba di dalam penelitian ini adalah dosen, guru mata pelajaran IPA, dan peserta didik SMP Negeri 1 Purbolinggo. Penelitian ini menggunakan instrumen yaitu berupa angket. Angket tersebut berfungsi sebagai alat bantu yang digunakan untuk pengambilan data penelitian, angket ini diisi oleh dosen dan guru mata pelajaran sebagai validator dan peserta didik.

Validasi dilakukan untuk pengumpulan data dengan menilai produk yang telah dibuat layak atau tidak untuk digunakan. Data yang diperoleh peneliti dalam proses validasi bersumber dari beberapa validator, yaitu 2 ahli desain, 2 ahli media, 2 ahli materi, 2 ahli tafsir dan guru. Setelah produk divalidasikan oleh ahli maka, selanjutnya direvisi terlebih dahulu produk yang telah dibuat agar dapat diujikan kepada peserta didik.

Tahap analisis data ini yaitu mengolah data yang telah diperoleh oleh peneliti. Pengumpulan data bertujuan untuk menghitung berapakah presentase kelayakan dan keterbacaannya sesuai dengan pernyataan yang telah diberikan, dalam perhitungan ini, menggunakan rumus sebagai berikut:

Nila $=\frac{\text { Rata }- \text { Rata Skor Validasi }}{\text { Jumlah Skor Maksimal }} \times 100 \%$

Sumber: Herdianawati (2013)

Menafsirkan persentase angket untuk mengetahui kelayakan modul secara keseluruhan dapat dilihat dalam Tabel 1.

Tabel 1. Kriteria Persentase Skor Penilaian

\begin{tabular}{|l|l|l|}
\hline Persentase & Kriteria & \multicolumn{1}{|c|}{ Ket. } \\
\hline $85 \%-100 \%$ & $\begin{array}{l}\text { Sangat } \\
\text { Baik }\end{array}$ & $\begin{array}{l}\text { Tidak } \\
\text { Perlu } \\
\text { Direvisi } \\
\text { Tidak } \\
\text { Perlu } \\
\text { Direvisi }\end{array}$ \\
\hline $75 \%-84 \%$ & Baik & $\begin{array}{l}\text { Perlu } \\
\text { Direvisi }\end{array}$ \\
\hline $55 \%-64 \%$ & $\begin{array}{l}\text { Cukup } \\
\text { Baik } \\
\text { Baik }\end{array}$ & $\begin{array}{l}\text { Perlu } \\
\text { Direvisi }\end{array}$ \\
\hline $0 \%-54 \%$ & $\begin{array}{l}\text { Sangat } \\
\text { Kurang } \\
\text { Baik }\end{array}$ & $\begin{array}{l}\text { Perlu } \\
\text { Direvisi }\end{array}$ \\
\hline
\end{tabular}

Sumber : Ramlan (2013)

Penelitian mengenai pengembangan ini, dikatakan berhasil jika mencapai kriteria kelayakan baik minimal pada skor $75 \%-84 \%$ Jika persentase $\leq 74 \%$ maka produk yang dikembangkan belum layak digunakan dan perlu direvisi kembali.

\section{HASIL}

Berdasarkan hasil wawancara dengan pendidik dan beberapa siswa (melalui Watsapp) pada tanggal 20 April 2020 di SMPN 1 Purbolinggo diperoleh data sebagai berikut; 1) proses pembelajaran menggunakan metode Daring (Dalam Jaringan) 2) Pembelajaran Daring mengugunakan aplikasi WhatsApp (WA) dimana tugas siswa di foto kemudian dikirimkan ke group WA kelas yang ini sangat menyulitkan wali kelas umtuk mengkoreksi jawaban 3) proses pembelajaran di SMP N 1 Purbolingggo 
masih menggunakan buku paket dan LKS, 4) belum pernah dikembangkan media pembelajaran berupa E- modul pembelajaran.

Berdasarkan hasil observasi tersebut maka perlu untuk dilakukannya analisis kebutuhan mengenai media yang digunakan dalam proses pembelajaran Daring khususnya dalam mata pelajaran IPA (biologi) yaitu sebagai menimbang permasalahan yang telah disampaikan diatas maka perlu untuk dikembangkan beberpa poin berikut, 1) Perlunya untuk mengembangkan media pembelajaran modul E-learning, 2) modul atau media yang dapat menunjang kegiatan pembelajaran Daring yang bertujuan siswa lebih paham terhadap materi pelajaran IPA terutama pada materi sistem organisasi kehidupan dengan memanfaatkan aplikasi Edmodo, 3) modul E-learning yang dikembangkan diharapkan dapat meningkatkan hasil belajar kognitif siswa.

\section{PEMBAHASAN}

Berdasarkan hasil penelitian Muhfahroyin (2018) menyatakan bahwa "implementasi pembelajaran dengan menggunakan e-learning dapat meningkatkan aktivitas belajar online siswa sebesar 43,19\%. Siswa lebih terampil dalam melakukan online diskusi, penugasan online yang berfungsi, mengunggah dan mengunduh file, dan kerja sama online. Peneliti juga merekomendasikan pendidik untuk meningkatkan aktivitas pembelajaran online dan keterampilan menggunakan elearning karena selain pembelajaran tatap muka, e-learning dapat digunakan sebagai media untuk membantu beberapa pembelajaran non-tatap muka (langsung). Siswa dilatih untuk melakukan aktivitas online dan terbiasa menggunakan jaringan virtual dalam menghadapi era digital revolusi industri 4.0".

Menurut Nurdani (2016:16-17) mengatakan bahwa "salah satu bentuk media pembelajaran berbasis e-learning yaitu edmodo. Edmodo (www.edmodo.com) adalah platform microblogging pribadi yang dikembangkan untuk guru dan siswa, dengan mengutamakan privasi siswa. Guru dan siswa dapat berbagi catatan, tautan, dan dokumen". Sedangkan menurut Sudibjo dan Wasis (2013: 188) mengatakan bahwa "di dalam edmodo ini, bisa berlangsung pembelajaran antara guru dan siswa, bahkan orang tua bisa mengkontrol anaknya saat pembelajaran berlangsung".

Menurut hasil penelitian Jumaeroh (2019) menyatakan bahwa "hasil uji angket juga menunjukkan bahwa kelas eksperimen lebih mudah menangkap materi pelajaran dengan menggunakan Edmodo jika dibandingkan dengan kelas kontrol yang masih melakukan pembelajaran secara konvensional".

Penelitian yang lain yaitu Miraza (2016) menyatakan bahwa "berdasarkan hasil angket yang telah diisi oleh responden sebanyak 34 orang siswa, diperoleh skor keseluruhan sebesar 45,58 dengan kategori amat baik untuk aspek media yang terdiri dari 14 butir pernyataan dan skor sebesar 20,02 dengan kategori amat baik untuk aspek materi yang terdiri dari 6 butir pernyataan. Berdasarkan hal tersebut dapat disimpulkan bahwa penggunaan media $e$ learning untuk mata pelajaran fisika pada materi gelombang bunyi dapat membantu siswa dalam proses belajar sehingga dengan adanya media e-learning pada materi gelombang bunyi dapat juga digunakan sebagai bahan ajar mandiri siswa di rumah".

Peneliti lain yang mendukung yaitu Ivaturrohmah (2018), Media pembelajaran elektronik dengan Edmodo di Internet subjek Plantae memiliki keefektifan yang tinggi dengan nilai rata-rata $\mathrm{N}$-Gain yang diperoleh pada SMAN 2 Jember di 0,76 dan di SMAN 4 Jember di 0.84. Tes kepraktisan untuk siswa menghasilkan persentase $84,44 \%$ dan $80,44 \%$. Tes kepraktisan untuk guru menghasilkan persentase sebesar $86,04 \%$ dan $83,125 \%$. Hasil kuesioner menyatakan bahwa media e-learning berbasis Edmodo memiliki tingkat kepraktisan yang sangat baik. 
Hasil penelitian Dharmawati (2017) mengatakan bahwa "pembelajaran English for Business dengan menggunakan edmodo mempunyai beberapa manfaat yang diperoleh yaitu meningkatkan interaksi antara dosen dan mahasiswa, membentuk sebuah kelas online, menambah variasi belajar, mengubah sistem pembelajaran yang tradisional menuju ke pembelajaran yang interaktif. Pembelajaran English for Business dengan memanfaatan edmodo membuat mahasiswa aktif dalam menggunakan bahasa Inggris mereka dengan cara memberi komentar dengan bahasa Inggris. Kesalahakesalahan yang terjadi dalam penggunaan bahasa Inggris adalah penggunaan tenses dan Tobe".

Penelitian lain yang medukung yaitu Hidayati (2019) mengatakan bahwa pembelajaran dengan menggunakan modul biologi sel dapat digunakan pada tingkatan pendidikan yang lebih tinggi meskipun memiliki tampilan yang sama seperti Emodul lainnya.

\section{KESIMPULAN}

Berdasarkan penjabaran yang telah dijelaskan di atas, dapat dikatakan bahwa modul pembelajaran biologi (IPA) berbasis E-learning dengan edmodo pada materi mengenai Sistem Organisasi Kehidupan dalam siswa kehidupan kelas VII SMP untuk meningkatkan hasil belajar kognitif siswa perlu dipertimbangkan sebagai penunjang dalam proses pembelajaran IPA.

\section{SARAN}

Saran yang dapat peneliti berikan pada penelitian pengembangan ini adalah sebagai berikut: a) Dalam mengembangkan sebuah media pembelajaran harus memperhatikan aspek daya guna yang panjang sehingga dapat dimanfaatkan dalam janga waktu yang panjang, b) Untuk menguji tingkat keterbacaan suatu media, maka penting untuk mempertimbangkan uji coba dalam skala yang lebih besar.

\section{DAFTAR RUJUKAN}

Arsyad, Azhar. 2007. Media Pembelajaran. Jakarta: PT. Rajagrafindo Persada.

DeLone, W. H. And McLean, E. R. 2003. The DeLone and McLean Model of Information Systems Success: A TenYear Update. Journal Management Information System, 19(4): 9-30

Dharmawati, 2017. Penggunaan Media eLearning Berbasis Edmodo Dalam Pembelajaran English for Business. QUERY: Jurnal Sistem Informasi. Vol.1/No.1

Herdianawati, Savitri, Fitrihidajati, Herliana dan Purnomo, Tarzan. 2013. Pengembangan Lembar Kegiatan Siswa (LKS) Inkuiri Berbasis Berpikir Kritis Pada Materi Daur Biogeokimia Kelas X. Jurnal Bio Edu Vol.2/NO.1.

Hidayati, Nuril, Pangestuti Ardian Anjar, dan Prayitno Trio Ageng . 2019. Edmodo mobile: developing emodule on biology cell for online learning community. Biosfer: Jurnal Pendidikan Biologi. 12 (1)

Ivaturrohmah1, Mudakir, Imam, Fikri , Kamalia. 2018. Development of Edmodo-Based E-Learning Media on the Plantae's Discussion for Learning Biological High School. Jurnal Bioedukasi. Vol. XVI. No. 2

Jumaeroh, Siti, Anggun Zuhaida. 2019. Pengaruh Media Edmodo Terhadap Hasil Belajar IPA pada Materi Tekanan dengan Model Discovery Learning. Jurnal. Journal of Natural Science Teaching. Vol. 02 No. 02 
Miraza, Retty, Jufrida \& Pathoni Haerul. 2016. Pengembangan Media E-Learning Berbasis Edmodo dengan Pendekatan Saintifik pada Materi Gelombang Bunyi. Jurnal Pendidikan Fisika Universitas Muhammadiyah Makassar. Vol 6 No 3

Mahnun, Nunu. 2012. Media Pembelajaran (Kajian terhadap Langkah-langkah Pemilihan Media dan Implementasinya dalam Pembelajaran). Jurnal Pemikiran Islam, Vol. 37 No. 1: 27.

Muhfahroyin and Eko Susanto. 2018. The Implementation of E-Learning to Improve Students' Virtual Activities. Journal of Physics. Conf. Series 1114 (2018) 012039

Nurdani, dan Alif Rahardhika. 2016. Penggunaan Media Edmodo Untuk Meningkatkan Hasil Belajar Siswa Pada Mata Pelajaran Dasar-Dasar Perhitungan Survei Pemetaan Kelas X Geomatika SMK N 3 Salatiga dan SMK N 1 Kedungwuni Pekalongan. Skripsi tidak diterbitkan. Semarang: Fakultas Teknik Uneversitas Negeri Semarang
Ramlan, Haeruddin, dan Kamaluddin. 2013. Pengembangan Media pembelajaran E-Materi dengan Model Pembelajaran Berbasis Masalah pada Materi Suhu dan Kalor. Jurnal Pendidikan Fisika Tadulako. No 2.

Sudibjo, Ari dan Wasis. 2013. Penggunaan Media Pembelajaran Fisika dengan E-Learning Berbasis Edmodo Blog Education pada Materi Alat Optik untuk Meningkatkan Respons Motivasi dan Hasil Belajar Siswa di SMP Negeri 4 Surabaya. Jurnal Inovasi Pendidikan Fisika, 2 (3): 188.

Trianto, 2011. Mendesain Model Pembelajaran Inovatif-Progresif. Jakarta: Kencana Prenada Group 